\title{
Erratum to: Modified Atkins diet in advanced malignancies-final results of a safety and feasibility trial within the Veterans Affairs Pittsburgh Healthcare System
}

Jocelyn L. Tan-Shalaby ${ }^{1,2^{*}}$, Jennifer Carrick ${ }^{1}$, Krystal Edinger ${ }^{1,2}$, Dana Genovese ${ }^{1,2}$, Andrew D. Liman ${ }^{1,2}$, Vida A. Passero ${ }^{1,2}$ and Rashmikant B. Shah ${ }^{1}$

\section{Erratum}

After publication of the original article [1], the author found that a word had been incorrectly used in the article body in the paragraph entitled 'Effect on the tumor' in the 'Results' section:

"The fourth patient, patient 17, an 84 year old with chemo-naive stage IV squamous cell lung carcinoma dieted until 16 weeks and finished the trial with stable disease while achieving excellent ketosis $(+2)$."

The word "squamous" should be "adenocarcinoma". Therefore the correct sentence should read "The fourth patient, patient 17 , an 84 year old with chemo-naive stage IV adenocarcinoma cell lung carcinoma dieted until 16 weeks and finished the trial with stable disease while achieving excellent ketosis $(+2) . "$

Received: 26 August 2016 Accepted: 26 August 2016

Published online: 01 September 2016

\section{Reference}

1. Tan-Shalaby et al. Modified Atkins diet in advanced malignancies - final results of a safety and feasibility trial within the Veterans Affairs Pittsburgh Healthcare System. Nutr Metab. (2016) 13:52. doi:10.1186/s12986-016-0113-y

\footnotetext{
* Correspondence: jocelyn.tan@va.gov

${ }^{1}$ Veteran Affairs Pittsburgh Healthcare System, Pittsburgh, Pennsylvania, USA

${ }^{2}$ University of Pittsburgh School of Medicine, Pittsburgh, Pennsylvania, USA
}

\footnotetext{
Submit your next manuscript to BioMed Central and we will help you at every step:

- We accept pre-submission inquiries

- Our selector tool helps you to find the most relevant journal

- We provide round the clock customer support

- Convenient online submission

- Thorough peer review

- Inclusion in PubMed and all major indexing services

- Maximum visibility for your research
}

Submit your manuscript at www.biomedcentral.com/submit 